\title{
CARD8 rs2043211 Polymorphism is Associated with Gout in a Chinese Male Population
}

\author{
Ying Chen ${ }^{a}$ Xianfeng Ren ${ }^{b}$ Changgui Lic Shichao Xing ${ }^{c}$ Zhengju Fu ${ }^{a}$ Ying Yuan ${ }^{a}$ \\ Robin Wang ${ }^{\text {a }}$ Yangang Wang ${ }^{\text {a }}$ Wenshan Lva \\ aDepartment of Endocrinology, Affiliated Hospital of Qingdao University, ${ }^{b}$ Department of Spine surgery, \\ Affiliated Hospital of Qingdao University, 'Shandong Provincial Key Laboratory of Metabolic Disease, \\ the Affiliated Hospital of Qingdao University Medical College, Qingdao, China
}

\section{Key Words \\ Gout • CARD8 • Polymorphism}

\begin{abstract}
Background \&Aim: Previous studies have suggested genetic factors are involved in the development of gout. We performed a case-control study to investigate the genetic association between CARD8 rs2043211 polymorphism and gout. Methods: A total of 396 male patients with gout and 403 age- and sex- matched healthy controls were included in this study. Genotyping was performed using TaqMan SNP Genotyping Assays. An association analysis was carried out using the $\chi 2$ test. The genotype-phenotype analysis was also conducted. Results: The genotype distribution of CARD8 rs2043211 polymorphism confirmed to HWE in the controls $(P=0.27)$. There was an obvious difference in the genotype distribution of CARD8 rs2043211 polymorphism between cases and controls $(P=0.017)$. In addition, there was an obvious association between CARD8 rs2043211 polymorphism and gout under the recessive comparison model (AA vs. TT/TA: OR $=0.65,95 \%$ CI $0.47-0.88, \mathrm{P}=0.006$ ). Patients carrying genotype TT of CARD8 rs2043211 polymorphism had higher triglycerides levels compared to those carrying the AA genotype $(2.77 \pm 2.08 \mathrm{mmol} / \mathrm{L}$ vs. $2.07 \pm 1.15 \mathrm{mmol} / \mathrm{L}, \mathrm{P}=0.01)$. Patients with the TT genotype also had significantly higher systolic blood pressure compared with those with the AA genotype $(142.11 \pm 21.10 \mathrm{mmHg}$ vs. $135.38 \pm 14.66 \mathrm{mmHg}, \mathrm{P}=0.03)$. Patients carrying TT genotype also had an increased risk of renal calculus compared with those carrying the AA genotype. Conclusion: CARD8 rs2043211 polymorphism is significantly associated with susceptibility to gout in Chinese Han males.
\end{abstract}




\begin{tabular}{|c|c|c|}
\hline Cellular Physiology & Cell Physiol Biochem 2015;35:1394-1400 & \\
\hline and Biochemistry & $\begin{array}{l}\text { DOI: 10.1159/000373960 } \\
\text { Published online: March 12, } 2015\end{array}$ & $\begin{array}{l}\text { O } 2015 \text { S. Karger AG, Basel } \\
\text { www.karger.com/cpb }\end{array}$ \\
\hline
\end{tabular}

\section{Introduction}

Gout is a disease caused by dysfunction in purine metabolism and decreased excretion of uric acid [1]. The clinical feature of gout is recurrent episodes of acute gouty arthritis, which can present as tophi, joint deformity, urinary lithiasis and other chronic symptoms $[1,2]$. Recently, with development of the economy and dietary changes, the prevalence and incidence of gout have risen rapidly [3, 4]. Epidemiological studies from China showed that the prevalence of gout was $1.94 \%$ in men and $0.42 \%$ in women in 2008 [5]. It has been known that both environmental factors and genetic factors have important roles in the development of gout $[1,6]$. Although the pathogenesis of gout is still unclear, accumulated studies indicate that genetic factors trigger gout development, such as some genes controlling the production and clearance of urate [6,7].

Previous studies have suggested that inflammation play an important role in the pathogenesis of gout [8, 9]. Accumulated evidences have implied that monosodium urate (MSU) crystal-induced inflammation is a paradigm of innate immunity and NALP3 inflammasome is involved in gout development [8-10]. NALP3 inflammasome contains NALP3, apoptosis-associated speck (ASC)-like protein and caspase activation and recruitment domain 8 (CARD8) $[11,12]$. Recent studies suggest that CARD8 functional mutations contribute to the development of autoinflammatory diseases including inflammatory bowel disease, rheumatoid arthritis, and Alzheimer's disease [13-17]. CARD8 is a component of innate immunity involved in the suppression of NF- $\kappa B$ (nuclear factor $\kappa B$ ) activation $[13,16]$. CARD8 can lead to the suppression of the immune response and suppression of inflammatory activities $[13,16]$. Several previous investigations have studied the association of a nonsense T30A polymorphism (rs2043211) in exon 5 with different inflammatory diseases including inflammatory bowel disease, rheumatoid arthritis, and Alzheimer's disease [13, 15-17]. Considering the important role of CARD8 in the inflammatory response, we hypothesized that CARD8 rs2043211 polymorphism may influence the risk of gout development. In present study, we performed a case-control study to examine the possible genetic association between CARD8 rs2043211 polymorphism and gout in a Chinese Han population.

\section{Materials and Methods}

\section{Study subjects}

A total of 396 male patients with gout and 403 age- and sex- matched healthy controls were included in this case-control study. All patients were consecutively recruited from the Department of Endocrinology or the gout laboratory at the Affiliated Hospital of the Qingdao University. The diagnosis of gout was based on preliminary criteria published by the America College of Rheumatology (ACR) in 1997 [18]. Samples from controls without a personal or familial history of hyperuricaemia or gout or other serious illness were collected. Blood glucose, uric acid, total cholesterol (TC), triglycerides (TG), urea nitrogen, and creatinine in the plasma were measured for all participants. Phenotypic characteristics included demographic data and clinical parameters (disease duration and disease-related complications), which were recorded using a standardized questionnaire. Visible or palpable tophi were determined from patients' arms, legs, knees, ears, olecranon processes, articula cartilage, and other sites. All subjects provided written informed consent, and the study protocol was approved by the Ethics Committee of the Affiliated Hospital of the Qingdao University.

\section{Genotyping}

Genomic DNA was isolated from leucocytes of venous blood, using the QIAamp DNA blood mini kit (Qiagen) and stored at $-20^{\circ} \mathrm{C}$. Samples were genotyped uniquely for polymorphisms rs 2043211 within the CARD8 gene using TaqMan SNP Genotyping Assays (Applied Biosystem) in the Bio-Rad CFX96TM RealTime System in combination with the C1000TM Thermal Cycler(Bio-Rad) by the following PCR program: initial denaturation for $3 \mathrm{~min}$ at $95^{\circ} \mathrm{C}$, then amplification for 40 cycles of $15 \mathrm{~s}$ at $95^{\circ} \mathrm{C}$ and $1 \mathrm{~min}$ at $60{ }^{\circ} \mathrm{C}$. All reactions included several components: mastermix $5 \mu \mathrm{L}$, which consisted of TaqMan qPCR supermix-UDG

\section{KARGER}




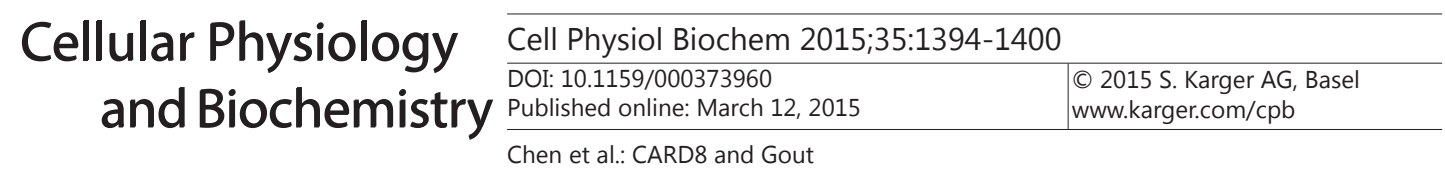

Table 1. Demographic and clinical characteristics of cases and controls. (BMI, Body mass index; TG, Triglycerides; TC, Total cholesterol)

\begin{tabular}{lccc}
\hline Parameters & Gout $(\mathrm{n}=396)$ & Control $(\mathrm{n}=403)$ & P values \\
\hline Age (years) & $50.33 \pm 11.98$ & $53.29 \pm 13.15$ & 0.054 \\
BMI $(\mathrm{kg} / \mathrm{m} 2)$ & $27.02 \pm 6.87$ & $24.98 \pm 4.17$ & 0.022 \\
Systolic blood pressure $(\mathrm{mmHg})$ & $138.02 \pm 18.65$ & $127.33 \pm 17.35$ & $<0.001$ \\
Diastolic blood pressure (mmHg) & $90.06 \pm 12.08$ & $83.25 \pm 9.73$ & $<0.001$ \\
Fasting blood glucose (mmol/L) & $6.17 \pm 1.74$ & $5.87 \pm 1.82$ & $<0.001$ \\
Uric acid $(\mu \mathrm{mo1} / \mathrm{L})$ & $470.46 \pm 116.79$ & $310.16 \pm 49.62$ & $<0.001$ \\
TG $(\mathrm{mmol} / \mathrm{L})$ & $2.38 \pm 1.75$ & $1.57 \pm 1.84$ & $<0.001$ \\
TC $(\mathrm{mmol} / \mathrm{L})$ & $5.22 \pm 1.25$ & $5.12 \pm 1.06$ & 0.011 \\
Urea nitrogen $(\mathrm{mmol} / \mathrm{L})$ & $5.682 \pm 2.20$ & $5.57 \pm 1.23$ & 0.075 \\
Creatinine $(\mu \mathrm{mo} / \mathrm{L})$ & $87.85 \pm 22.65$ & $78.06 \pm 15.64$ & $<0.001$ \\
\hline
\end{tabular}

(Invitrogen), 50nM MgCl2 and ROX reference dye according to mixing ratio of 25:4:1, 40× SNP Genotyping Assay mix $0.25 \mu \mathrm{L}$ (the final assay mix concentration is $1 \mathrm{X}$ ) which contains a pair of Sequence-specific primers 5'-AGTTGACACTCAGGAACA GCACGGA[A/T]CAATAATGGCTCTGCCTCTGTCTCA-3' and two TaqMan $®$ probes separately labeled with FAM ${ }^{\mathrm{TM}}$ and VIC $®$ dye, 50ng of purified DNA and $\mathrm{H} 2 \mathrm{O}$ up to the final volume of $10 \mathrm{uL}$.

\section{Statistical analysis}

SPSS version 17.0 (SPSS Inc, Chicago, IL, USA) was used for the statistical analysis. The student t-test was used to assess a significant difference in demographic and clinical characteristics between cases and controls. A goodness-of- fit $\chi 2$ test was used to examine Hardy-Weinberg equilibrium (HWE) in the controls. Pearson's $\chi 2$ test was used to compare the genotype and allele frequencies between controls and patients. Odds ratios (ORs) and 95\% confidence intervals (CIs) were used as a measure of the strength of relationship in the genotype distribution and allele frequencies between cases and controls. An analysis of variance (ANOVA) was used for a genotype-phenotype analysis of the gout patients. P-values $<0.05$ were considered statistically significant.

\section{Results}

Demographic and clinical characteristics of the participants

The clinical characteristics of the participants enrolled in the study were summarized in Table 1 . The results showed that gout patients had significantly higher levels of body mass index (BMI), systolic blood pressure, diastolic blood pressure, fasting blood glucose, TC, TG, and uric acid than the controls $(\mathrm{P}<0.05)$ (Table 1). There was no obvious difference between gout patients and controls in the other characteristics.

CARD8 rs2043211 polymorphism and gout

The genotype distribution of CARD8 rs2043211 polymorphism confirmed to HWE in the controls $(\mathrm{P}=0.27)$. Table 2 listed the association between CARD8 rs2043211 polymorphism and gout (Table 2). There was an obvious difference in the genotype distribution of CARD8 rs2043211 polymorphism between cases and controls $(\mathrm{P}=0.017)$. However, there tended to be significant difference in allelic frequencies between gout cases and controls $(\mathrm{OR}=0.84$, 95\%CI 0.69-1.02; $\mathrm{P}=0.08$ ) (Table 2). In addition, there was an obvious association between CARD8 rs2043211 polymorphism and gout under the recessive comparison model (AA vs. TT/TA: OR $=0.65,95 \% \mathrm{CI} 0.47-0.88, \mathrm{P}=0.006$ ). However, there was no significant association between CARD8 rs2043211 polymorphism and gout under the other comparison models (Table 2). 


\begin{tabular}{|c|c|c|}
\hline Cellular Physiology & Cell Physiol Biochem 2015;35:1394-1400 & \\
\hline and Biochemistry & $\begin{array}{l}\text { DOI: 10.1159/000373960 } \\
\text { Published online: March 12, } 2015\end{array}$ & $\begin{array}{l}\text { O } 2015 \text { S. Karger AG, Basel } \\
\text { www.karger.com/cpb }\end{array}$ \\
\hline
\end{tabular}

Table 2. Associations between CARD8 rs2043211 polymorphism and gout

\begin{tabular}{lcccc}
\hline & $\begin{array}{c}\text { Gout } \\
(\mathrm{n}=396)\end{array}$ & $\begin{array}{c}\text { Control } \\
(\mathrm{n}=403)\end{array}$ & $\begin{array}{c}\text { OR } \\
(95 \% \mathrm{CI})\end{array}$ & P value \\
\hline Genotypes & & & & \\
TT & 88 & 89 & -- & -- \\
AT & 219 & 189 & $1.17(0.82-1.67)$ & 0.38 \\
AA & 89 & 125 & $0.72(0.48-1.07)$ & 0.11 \\
Alleles & & & & \\
T & 395 & 367 & -- & -- \\
A & 397 & 439 & $0.84(0.69-1.02)$ & 0.08 \\
\hline
\end{tabular}

Table 3. Genotype-phenotype analysis in our study. (BMI, Body mass index; TG, Triglycerides; TC, Total cholesterol)

\begin{tabular}{|c|c|c|c|c|c|}
\hline Characteristics (mean \pm SD) & TT $(\mathrm{n}=88)$ & $\operatorname{AT}(\mathrm{n}=219)$ & $\mathrm{AA}(\mathrm{n}=89)$ & $\begin{array}{c}\text { P value for ANOVA } \\
\text { analysis }\end{array}$ & $\begin{array}{c}\text { P value for TT } \\
\text { vs. AA } \\
\end{array}$ \\
\hline Age (years) & $54.49 \pm 12.82$ & $52.71 \pm 13.71$ & $51.94 \pm 12.47$ & 0.43 & 0.21 \\
\hline Age at diagnosis (years) & $49.08 \pm 13.27$ & $46.51 \pm 13.48$ & $47.31 \pm 13.30$ & 0.34 & 0.41 \\
\hline Disease duration (years) & $5.54 \pm 5.19$ & $6.31 \pm 6.03$ & $4.78 \pm 4.72$ & 0.11 & 0.38 \\
\hline BMI (kg/m2) & $26.82 \pm 3.09$ & $26.64 \pm 3.30$ & $26.08 \pm 3.06$ & 0.91 & 0.77 \\
\hline $\begin{array}{l}\text { Systolic blood pressure } \\
\text { (mmHg) }\end{array}$ & $142.11 \pm 21.10$ & $139.18 \pm 20.14$ & $135.38 \pm 14.66$ & 0.08 & 0.03 \\
\hline $\begin{array}{l}\text { Diastolic bolld pressure } \\
\text { (mmHg) }\end{array}$ & $92.23 \pm 11.91$ & $90.95 \pm 13.88$ & $88.62 \pm 11.06$ & 0.19 & 0.07 \\
\hline $\begin{array}{l}\text { Fasting blood glucose } \\
(\mathrm{mmol} / \mathrm{L})\end{array}$ & $5.97 \pm 1.43$ & $6.19 \pm 1.73$ & $6.24 \pm 2.19$ & 0.56 & 0.33 \\
\hline Uric acid $(\mu \mathrm{mo} 1 / \mathrm{L})$ & $471.16 \pm 129.47$ & $483.58 \pm 108.01$ & $467.40 \pm 115.92$ & 0.48 & 0.83 \\
\hline $\mathrm{TG}(\mathrm{mmol} / \mathrm{L})$ & $2.77 \pm 2.08$ & $2.41 \pm 1.84$ & $2.07 \pm 1.11$ & 0.04 & 0.01 \\
\hline $\mathrm{TC}(\mathrm{mmol} / \mathrm{L})$ & $5.26 \pm 1.18$ & $5.25 \pm 1.29$ & $5.31 \pm 1.26$ & 0.73 & 0.81 \\
\hline Urea nitrogen $(\mathrm{mmol} / \mathrm{L})$ & $5.88 \pm 1.97$ & $5.98 \pm 3.11$ & $6.12 \pm 3.48$ & 0.89 & 0.63 \\
\hline Creatinine $(\mu \mathrm{mo} 1 / \mathrm{L})$ & $89.47 \pm 26.26$ & $95.44 \pm 63.45$ & $91.78 \pm 34.18$ & 0.68 & 0.78 \\
\hline Tophi and renal calculus (n) & $20 / 88$ & $26 / 219$ & $10 / 89$ & 0.03 & 0.04 \\
\hline
\end{tabular}

Genotype-phenotype analysis

Table 3 showed the results of genotype-phenotype analysis (Table 3). There was obvious difference in the TG levels among those three genotypes (Table 3). There was also significant difference in the number of tophi and renal calculus between individuals carrying the TT, AT and AA genotype of rs2043211 ( $\mathrm{P}=0.03)$. Patients carrying genotype TT of CARD8 rs2043211 polymorphism had higher TG levels compared to those carrying the AA genotype $(2.77 \pm 2.08 \mathrm{mmol} / \mathrm{L}$ vs. $2.07 \pm 1.15 \mathrm{mmol} / \mathrm{L}, \mathrm{P}=0.01)$. Patients with the TT genotype also had significantly higher systolic blood pressure compared with those with the AA genotype $(142.11 \pm 21.10 \mathrm{mmHg}$ vs. $135.38 \pm 14.66 \mathrm{mmHg}, \mathrm{P}=0.03)$. Patients carrying TT genotype also had an increased risk of renal calculus compared with those carrying the AA genotype $(\mathrm{P}=0.03)$.

\section{Discussion}

As a kind of autoinflammatory disorder, gout is a common inflammatory arthritis characterized by the deposition of MSU crystals within the joints or soft tissues after chronic hyperuricaemia $[9,19]$. Recent studies have suggested that MSU crystals might function as a danger signal released from injured cells and trigger an innate immune response in KARGER 
a manner similar to microbial molecules, implying gouty arthritis as a paradigm of innate immunity [20, 21]. The NALP3 inflammasome, including CARD8 can control inflammatory caspase-1-mediated IL-1 release and is involved in MSU crystals-mediated gouty arthritis $[22,23]$.

In the present study, we performed a case-control study to examine the possible genetic association between CARD8 rs2043211 polymorphism and gout in a Chinese Han population. We found that there was an obvious difference in the genotype distribution of CARD8 rs2043211 polymorphism between cases and controls $(P=0.017)$. In addition, there was an obvious association between CARD8 rs2043211 polymorphism and gout under the recessive comparison model (AA vs. TT/TA: OR $=0.65,95 \%$ CI $0.47-0.88, \mathrm{P}=0.006$ ). To the best of our knowledge, this is the first study to report the association between polymorphisms of CARD8 and gout. In the genotype-phenotype analysis, we found that patients carrying genotype TT showed higher TG levels compared to those carrying the genotype AA. TG levels showed a significantly different distribution among those three different genotypes. Hypertriglyceridemia is a risk factor of gout, and the genotype-phenotype analysis in our study indicates that CARD8 rs2043211 polymorphism is associated with TG levels, which further proves the association between CARD8 rs2043211 polymorphism and susceptibility to gout.

Inflammation has vital roles in many diseases including gout $[1,9,24,25]$. The CARD8 protein is encoded by the 13 exons of the CARD8 gene on chromosome $19 q 13[26,27]$. CARD-8 interacts physically with caspase- 1 and negatively regulates caspase-1-dependent IL-1b expression and nuclear factor NF- $\kappa B$ activation [26, 27]. The CARD8 rs2043211 polymorphism introduces a premature stop codon, which results in the expression of a severely truncated protein. The variant CARD8 is unable to suppress NF- $\kappa \mathrm{B}$ activity, which leads to high constitutive levels of pro-IL-1b $[16,26,27]$. In the current study, we found that the prevalence of the TT variant genotype was significantly higher in gout patients than in controls. Thus, there is a possibility that increased expression of CARD-8 due to higher promoter activity of the TT genotype may induce a predominantly inflammatory immune response leading to increased susceptibility to gout.

However, the present study had several limitations. Firstly, we only chose one single nuclide polymorphism of CARD8 and did not include enough number of polymorphic markers to cover the whole sequence of CARD8. So, the results of the present study should be interpreted with caution. Secondly, the sample size in our research was small, and all subjects were from Chinese Han population. Our findings need to be validated in other ethic populations and in more studies with larger sample size. Finally, the mechanism underling the association between CARD8 rs2043211 polymorphism and susceptibility to gout is still unclear. Further experimental studies are needed to explore the role of CARD8 rs2043211 polymorphism on gout risk.

In conclusion, CARD8 rs2043211 polymorphism is significantly associated with susceptibility to gout in Chinese Han males. In addition, our findings need to be validated in other ethic populations and in more studies with larger sample size.

\section{Acknowledgments}

This work was supported by the National Natural Science Foundation of China (81100554), Young and Middle-Aged Scientists Research Awards Fund of Shandong Province (BS2012YY003), the Scientific and Technical Development Project of Department of health of Shandong Province(2011QZ007), a Project of Shandong Province Higher Educational Science and Technology Program (J14LK11) and the Scientific and Technical Development Project of Qingdao (12-1-4-20-jc, 2012-1-3-2-(1)-nsh ,2014-1-72 and 2013-13-008-YY).

\section{Disclosure Statement}

All authors declare that they have no conflicts of interest.

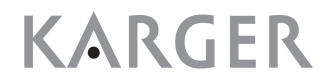




\section{Cellular Physiology Cell Physiol Biochem 2015;35:1394-1400 \begin{tabular}{l|l} 
and Biochemistry Published online: March 12, 2015 & $\begin{array}{l}\text { DO 2015 S. Karger AG, Basel } \\
\text { www.karger.com/cpb }\end{array}$ \\
\hline
\end{tabular} \\ Chen et al.: CARD8 and Gout}

\section{References}

1 Roddy E, Mallen CD, Doherty M: Gout. BMJ 2013;347:f5648.

2 Ning TC, Keenan RT: Unusual clinical presentations of gout. Curr Opin Rheumatol 2010;22:181-187.

3 Roddy E, Choi HK: Epidemiology of gout. Rheum Dis Clin North Am 2014;40:155-175.

4 Smith E, Hoy D, Cross M, Merriman TR, Vos T, Buchbinder R, Woolf A, March L: The global burden of gout: Estimates from the global burden of disease 2010 study. Ann Rheum Dis 2014;73:1470-1476.

5 Miao Z, Li C, Chen Y, Zhao S, Wang Y, Wang Z, Chen X, Xu F, Wang F, Sun R, Hu J, Song W, Yan S, Wang CY: Dietary and lifestyle changes associated with high prevalence of hyperuricemia and gout in the shandong coastal cities of eastern china. J Rheumatol 2008;35:1859-1864.

6 Merriman TR, Choi HK, Dalbeth N: The genetic basis of gout. Rheum Dis Clin North Am 2014;40:279-290.

7 Reginato AM, Mount DB, Yang I, Choi HK: The genetics of hyperuricaemia and gout. Nat Rev Rheumatol 2012;8:610-621.

8 Cronstein BN, Sunkureddi P: Mechanistic aspects of inflammation and clinical management of inflammation in acute gouty arthritis. J Clin Rheumatol 2013;19:19-29.

9 Schlesinger N, Thiele RG: The pathogenesis of bone erosions in gouty arthritis. Ann Rheum Dis 2010;69:1907-1912.

10 MacFarlane LA, Kim SC: Gout: A review of nonmodifiable and modifiable risk factors. Rheum Dis Clin North Am 2014;40:581-604.

11 Carlstrom M, Ekman AK, Petersson S, Soderkvist P, Enerback C: Genetic support for the role of the nlrp3 inflammasome in psoriasis susceptibility. Exp Dermatol 2012;21:932-937.

12 Miao ZM, Zhao SH, Yan SL, Li CG, Wang YG, Meng DM, Zhou L, Mi QS: Nalp3 inflammasome functional polymorphisms and gout susceptibility. Cell Cycle 2009;8:27-30.

13 von Kampen O, Lipinski S, Till A, Martin SJ, Nietfeld W, Lehrach H, Schreiber S, Rosenstiel P: Caspase recruitment domain-containing protein 8 (card8) negatively regulates nod2-mediated signaling. J Biol Chem 2010;285:19921-19926.

14 Bouchier-Hayes L, Conroy H, Egan H, Adrain C, Creagh EM, MacFarlane M, Martin SJ: Cardinal, a novel caspase recruitment domain protein, is an inhibitor of multiple nf-kappa b activation pathways. J Biol Chem 2001;276:44069-44077.

15 McGovern DP, Butler H, Ahmad T, Paolucci M, van Heel DA, Negoro K, Hysi P, Ragoussis J, Travis SP, Cardon LR, Jewell DP: Tucan (card8) genetic variants and inflammatory bowel disease. Gastroenterology 2006;131:1190-1196.

16 Fontalba A, Martinez-Taboada V, Gutierrez O, Pipaon C, Benito N, Balsa A, Blanco R, Fernandez-Luna JL: Deficiency of the nf-kappab inhibitor caspase activating and recruitment domain 8 in patients with rheumatoid arthritis is associated with disease severity. J Immunol 2007;179:4867-4873.

17 Fontalba A, Gutierrez O, Llorca J, Mateo I, Berciano J, Fernandez-Luna JL, Combarros O: Deficiency of card8 is associated with increased alzheimer's disease risk in women. Dement Geriatr Cogn Disord 2008;26:247250.

18 Khanna D, Khanna PP, Fitzgerald JD, Singh MK, Bae S, Neogi T, Pillinger MH, Merill J, Lee S, Prakash S, Kaldas M, Gogia M, Perez-Ruiz F, Taylor W, Liote F, Choi H, Singh JA, Dalbeth N, Kaplan S, Niyyar V, Jones D, Yarows SA, Roessler B, Kerr G, King C, Levy G, Furst DE, Edwards NL, Mandell B, Schumacher HR, Robbins M, Wenger N, Terkeltaub R: 2012 american college of rheumatology guidelines for management of gout. Part 2: Therapy and antiinflammatory prophylaxis of acute gouty arthritis. Arthritis Care Res (Hoboken) 2012;64:1447-1461.

19 Perez-Ruiz F, Castillo E, Chinchilla SP, Herrero-Beites AM: Clinical manifestations and diagnosis of gout. Rheum Dis Clin North Am 2014;40:193-206.

20 Schauer C, Janko C, Munoz LE, Zhao Y, Kienhofer D, Frey B, Lell M, Manger B, Rech J, Naschberger E, Holmdahl R, Krenn V, Harrer T, Jeremic I, Bilyy R, Schett G, Hoffmann M, Herrmann M: Aggregated neutrophil extracellular traps limit inflammation by degrading cytokines and chemokines. Nat Med 2014;20:511-517.

21 Reber LL, Marichal T, Sokolove J, Starkl P, Gaudenzio N, Iwakura Y, Karasuyama H, Schwartz LB, Robinson WH, Tsai M, Galli SJ: Contribution of mast cell-derived interleukin-1beta to uric acid crystal-induced acute arthritis in mice. Arthritis Rheumatol 2014;66:2881-2891. 


\section{Cellular Physiology Cell Physiol Biochem 2015;35:1394-1400}

and Biochemistry Published online: March 12, 2015

Chen et al.: CARD8 and Gout

22 Martinon F, Petrilli V, Mayor A, Tardivel A, Tschopp J: Gout-associated uric acid crystals activate the nalp3 inflammasome. Nature 2006;440:237-241.

23 Verma D, Lerm M, Blomgran Julinder R, Eriksson P, Soderkvist P, Sarndahl E: Gene polymorphisms in the nalp3 inflammasome are associated with interleukin-1 production and severe inflammation: Relation to common inflammatory diseases? Arthritis Rheum 2008;58:888-894.

24 Cox AJ, West NP, Cripps AW: Obesity, inflammation, and the gut microbiota. Lancet Diabetes Endocrinol 2014.

25 Scheen AJ, Van Gaal LF: Combating the dual burden: Therapeutic targeting of common pathways in obesity and type 2 diabetes. Lancet Diabetes Endocrinol 2014;2:911-922.

26 Srinivasula SM, Poyet JL, Razmara M, Datta P, Zhang Z, Alnemri ES: The pyrin-card protein asc is an activating adaptor for caspase-1. J Biol Chem 2002;277:21119-21122.

27 Razmara M, Srinivasula SM, Wang L, Poyet JL, Geddes BJ, DiStefano PS, Bertin J, Alnemri ES: Card-8 protein, a new card family member that regulates caspase-1 activation and apoptosis. J Biol Chem 2002;277:1395213958. 